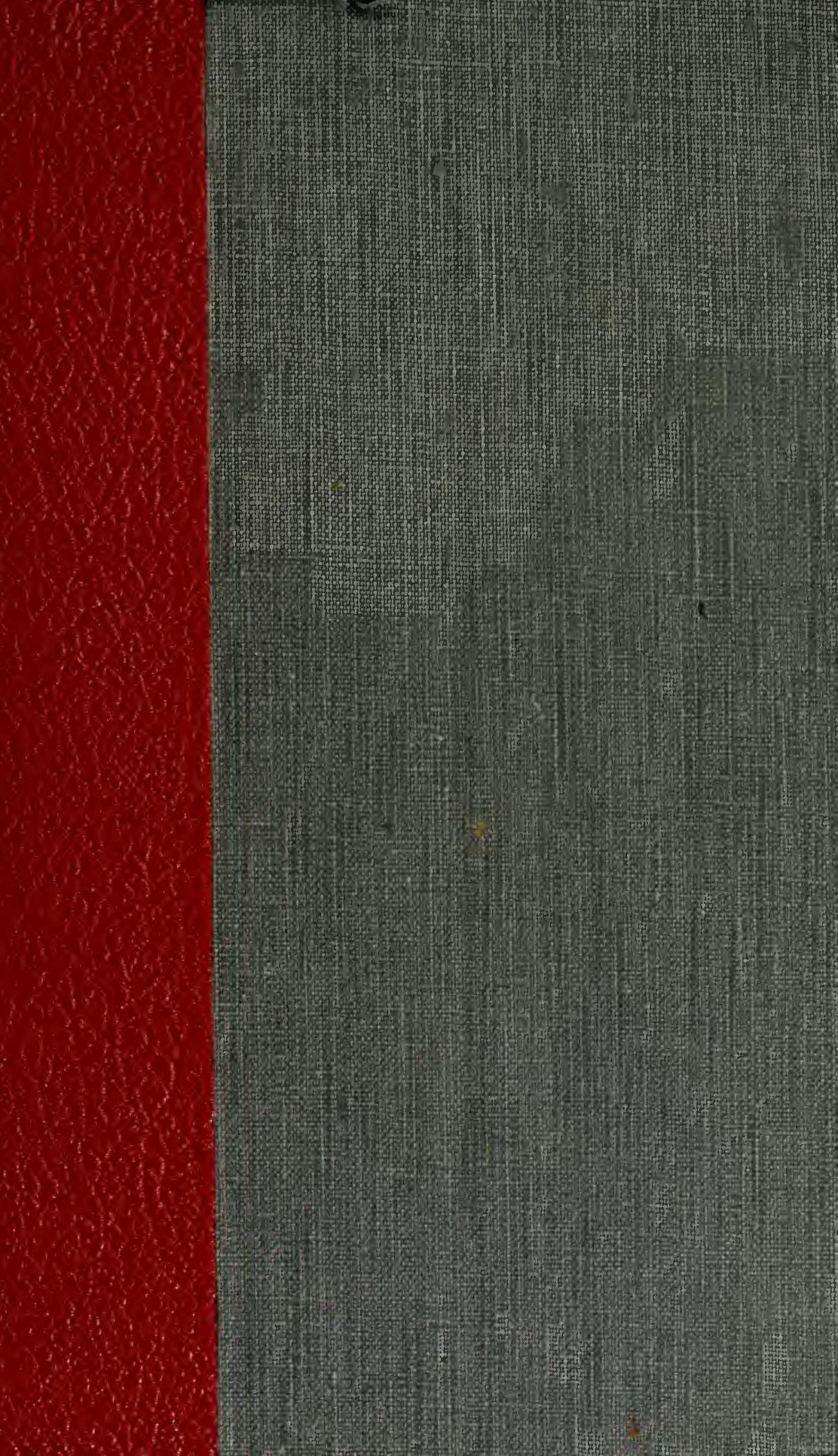




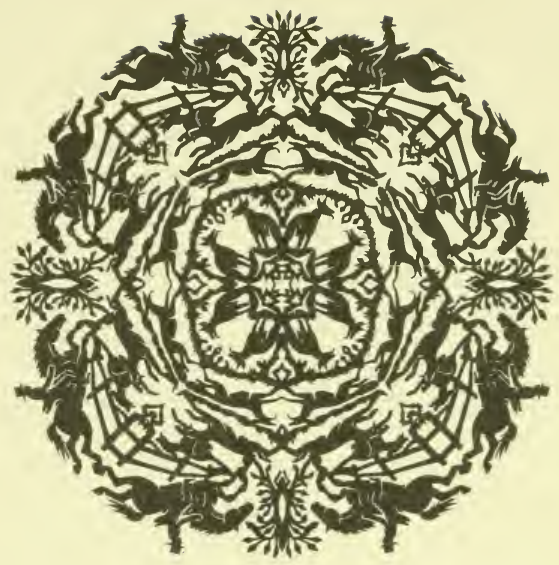

JOHN A.SEAVERNS 




\section{LECTURES}

ON

\section{HORSEMANSHIP,}

Wherein is Explained

EVERY

NECESSARY INSTRUCTION

FOR BOTH

$\therefore$ LADIES AND GENTLEMEN, In the Ufeful and Polite
A R T
OF
R I D I N
G,

\section{WITH}

Fa SE, ELEGAHCE, AND SAFETY,

$$
\text { BY T. S. }
$$

Profeffor of Horfemanilhip.

LONDON:

1793. 


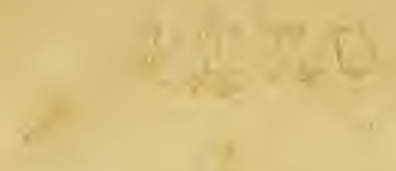

$$
2+y^{2}+x^{2}+5
$$

10.78 70

$x$
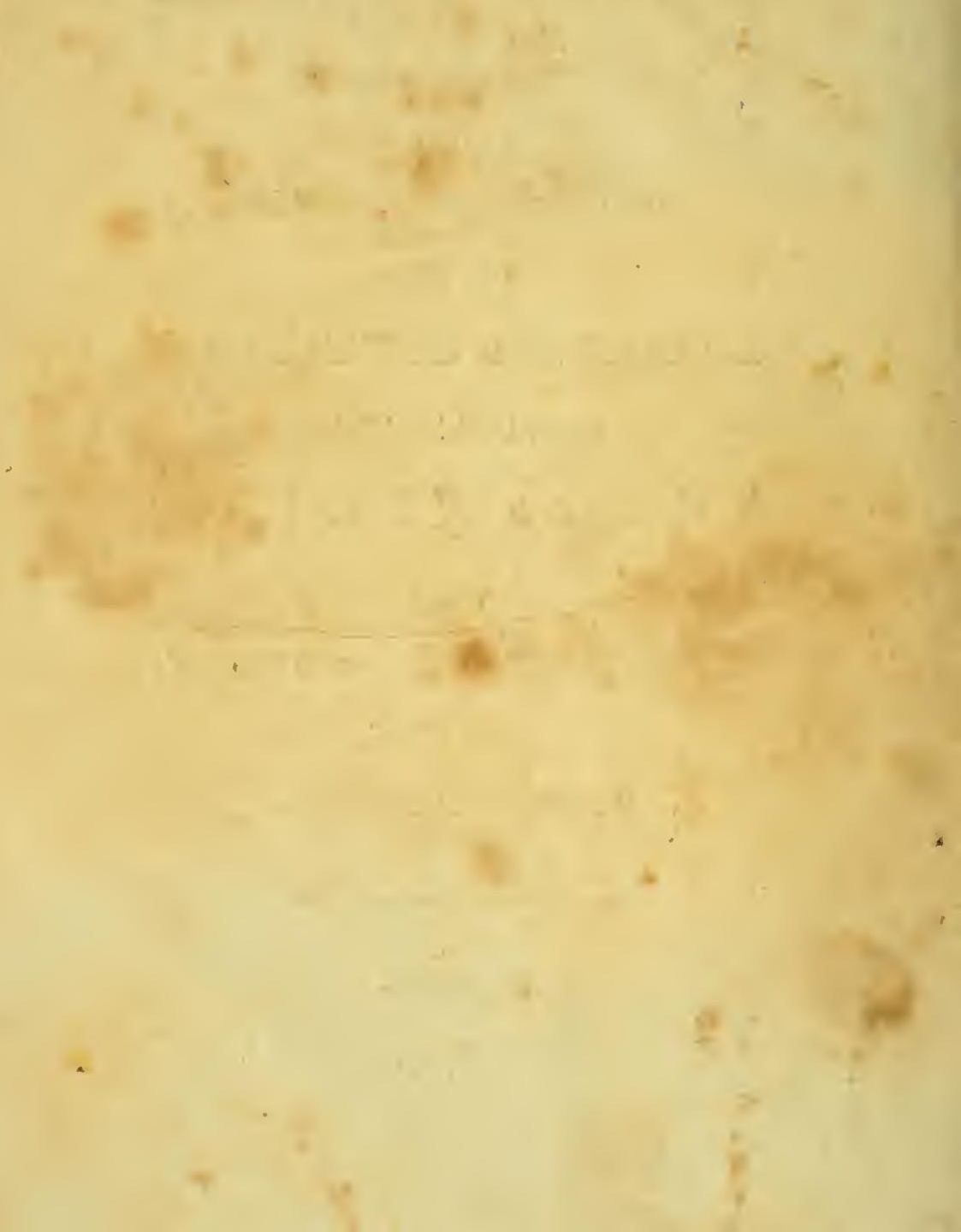


\section{LECTURE ON HORSEMANSHIP.}

\section{Addrers to the Audience.}

\section{LADIES AND GENTLEMEN.}

PERMIT me to obferve that the Horle is an animal, which, from the earlieft ages of the world, has been deftined to the pleafure and fervices of Man; the various and noble qualities with which nature has endowed him fufficiently fpeaking the ends for which he was defigned.

Mankind were not long before they were acquainted with them, and found the means of applying them to the purpofes for which they were given: this is apparent from the Hiftories and traditions of almoft all nations, even from times the moft remote; infomuch that many nations and tribes, or colonies of people, who were entirely ignorant, or had but very imperfect notions, of other improvements and arts of life; -and even at this day *are unacquainted with them, yet faw and underftood the generous properties of this creature in fo ftrong a light as to treat him with fondnefs and the greateft attention, fufficiently to declare the high opinion they entertained of his

* Such as the Wild Arabs, Indians, \&c. 


\section{(4)}

merit and excellence; nay in various regions, and in the moft diftant ages, were fo fur from being ftrangers to the many fervices of which the Horfe was capable, as to have left rules and precepts concerning them, which are fo true and juft, that they have been adopted by their fucceffors; and as all art is progreffive, and receives additions and improvements in its courfe, as the fagacity of man at different times, or chance and other caufes happen and concur: fo that having the Ancient's foundation to erect our building, it is natural to fuppofe that the fructure has received many beauties and improvements from the experience and refinement of latter times.

It is generally fuppoled that the firft fervice in which the Horfe was employed, was to affift mankind in making war, or in the pleafures and occupations of the chafe. Xenophon, who w rote three hundred years before the Birth of Chrift, fays, in an exprefs treatife which he wrote on Horfemanfhip, that Cyrus hunted on Horfeback, when he had a mind to exercife himfelf and horfes.

Herodotus fpeaks of hunting on Horfeback as an exercife ufed in the time of Darius, and it is probably of much earlier date. He particulatly mentions a fall which Darius had from his horfe in hunting, by which he diflocated his heel : thefe and thoufands of quotations more, which might be produced as proofs of the utility of the Horfe, in remote ages, are truths fo indifputably attefted that to enlarge farther upon it would be a fuperfluous labour, and foreign to my prefent undertaking. 
On Mounting Your Horse.

FIRST we will fuppofe your horfe properly faddled and bridled. Take your Bridoun-rein (if you have Bit and Bridoun)in your right-hand, fhifting it till you have found the center of the rein; then with your fwitch or whip in your left-hand, place your little finger between the reins, fo that the right rein lies flat in your hand upon three fingers, and your thumb preffing your left rein Hat upon the right, keeping your thumb both upon right and left rein, firm upon your fore-finger; and in this pofition you eafe your hand a little and flide it firmly down the reins upon your horfe's neck, taking a firm hold of a lock of his mane, which will afift you in fpringing to mount: remember that when you attempt to mount, that your reins are not fo tight as to check your horfe, or to offend his mouth, fo as to caufe him to rear, or rein back, but that your action is finooth and light as poffible.

Your horfe being firmly ftayed, you next take your Stirrup-leather in your Right.hand, about four inches from the ftirrup.iron, and fix one third of your toot in the ftirrup, ftanding fquare with your horfe's fide; next take a firm hold with your 
right hand on the Cantlet or back part of the faddle, rather on the off fide of it, and with your left knee preft firm againft the horfe's fide, fpring yourfelf up perpendicularly, bending the fmall of your back and looking chearfully up rather than down. The next move you make is to remove your right-hand from the Cantlet and place it firm upon the Pummel, or front of your faddle, bearing your weight upon it, at the fame time bend your right knee, and bring your body round, looking ftrait over your horfe's head, letting yourfelf firmly and eafily down into your feat, with the houlders eafily back, bent well in your waift or loins, and your cheft well prefented in front, with a pleafant uncontracted countenance.

You of courfe next recover or take your fwitch, which is done by putting your right-hand over your left, and with a quick firm motion take it in your right hand, holding the fame perpendicularly.

Proceed us next to the adjufting the Reins, which is of the utmoft ufe. Suppofing you ride with Bit and Bridoun, being four in number, place them all even and flat in your left hand, exactly in the fame manner as defcribed in taking the Bridoun in mounting; that is to fay, your four reins placed even, the one upon the other, remembering always to place your Bridouns on the outfides, fo that you may any time lengthen or thorten them at pleafure, without putting the whole into confufion, and caufe the Bit to act alone, or Bridoun alone, or both Bit and Bridoun to act together.

I have obferved before that only your little finger mould be between the reins when only two, it is the fame now four, fo now your two reins on the 
right fide of your horfe's neck lie flat upon your three fingers in your left-hand, your two left reins placed flat upon the right, and your thumb preffed flat upon all four. This is the only fure method to keep your reins firm, free from confufion, and to caufe them to act properly; which any lady or gentleman will be convinced of if they will only give themfelves the pleafure to practife, as I cannot call it a trouble.

If it fhould be demanded why the horfe would not ride as well with only the Bridoun, without the Bit? my anfwer is that fuppofe your horfe becomes hard and heavy in hand, on being rode by both Bit and Bridoun, where they have both acted together: you on this fhorten your Bit-reins whereby they act alone the Bridouns becoming flack, your horfe inftantly becomes light in hand, as though touched by a magick fick, reining his neck properly, is immediately light before, gathers himfelf upon his haunch es, and what appeared, but now a garronly flugginh beaft wears the appearance of a well dreffed horfe.

Well and thorough broke horfes with mouths made fine and to anfwer the niceft touch of feeling, are in general rode by the Bit alone, the Bridouns hanging loofe and feem more for ornament than ufe; but yet in the hand of a fkillful horfeman are of the greateft utility; for by handling your right Bridoun-rein lightly with your whip hand at proper times; you can always raife your horfe's head if too low, you may take the liberty of eafing your Bit-reins at times, fo that playing upon his mouth, as it were an Inftir. ment of mujick, you will always keep his mouth in tune. I cannot find a jufter fimile than, that the Horfe is the Inftrument and the Rider the Player; 


\section{(8)}

and when the horfe is well broke and tuned properly, and the rider knows how to keep him in that ftate, he is never at a lofs to play upon him; but if fuffered to go out of tune, by the want of fkill in the horfeman, and to imbibe bad habits, the horfeman not being able to fcrew him up, and tune him as before: the Inftrument is thrown by as ufelefs, or may be fold for a trifle, and by chance falling into able hands, that know how to manage and put him once more together; he again becomes as good as ever : and this I have often been a witnefs to. Thus much for the adjuftment of the Reins in the Hand.

\section{The Horseman's Seat:}

THE principles and rules which have hitherto been given for the horfeman's feat are various, and even oppofite, according as they have been adopted by different mafters, and taught in different countries, almoft by each mafter in particular; and every nation having certain rules and notions of their own. Let us fee, however, if art has difcovered nothing that is certain and invariably true.- The Italians, the Spaniards, the French and, in a word, every country where Riding is in repute, adopt each a pofture which is peculiar to themfelves: the foundation of their general notions is the fame, but each country has prefcribed rules for the placing the man on the faddle.

This contrariety of opinions which have their origin more in prejudice than in truth and reality, has given rife to many vain reafonings and fpeculations, each Syftem having its followers; and as if truth was not always the fame, and unchangeable, but at liber- 
ty to affume various and even oppofite hapes; fometimes one opinion prevailed, fometimes another, infomuch that thofe who underftand nothing of the fubject, but yet are defirous of being informed, by fearching it to the bottom, have hitherto been loft in doubt and perplexity.

There is neverthelefs a fure and infallible method, by the affiftance of which it would be very eafy to overturn all thefe fyftems; but not to enter into a needlefs detail of the extravagant notions, which the Seat alone has given rife to; I will here endeavour to trace it from principles by fo much the more folid, as their authority will be fupported by the moft convincing and felf evident reafons.

In order to fucceed in an art where the mechanifm of the body is abfolutely neceffary, and where each part of the body has its proper functions, which are peculiar to that part; it is moft certain that all and every part of the body fhould be in a natural pofture : were they in an imperfect fituation they would want that eafe and freedom which is infeparable from grace; and as every motion which is conftrained being falfe in itfelf, and incapable of juftnefs, it is clear that the part fo conftrained and forced would throw the whole into confufion; becaufe each part belonging to and depending upon the whole body, and the body partaking of the conftraint of its parts, can never feel that fixed point, that juft counterpoife and equality, in which alone a fine and juft execution confifts.

The abjects to which a mafter, anxious for the advancement of his pupil, fhould attend, are infinite. 'To little purpofe will it be to keep the flricteft eye 
upon all the parts and Limbs of his pupil's Body; in vain will he endeavour to remedy all the defects and faults which are found in the pofture of almoft every fcholar in the beginning, unlefs he is intimately acquainted with the clofe dependance and connexion there is between the motions of one part of the body with the reft; a correfpondence caufed by the reciprocal action of the mufcles, which govern and direct them: unlefs, therefore, he is mafter of this fecret, and has his clue to the labyrinth, he will never attain the end he propofes; particularly in his firft leffons, upon which the fuccefs of the reft always depend. Thefe principles being eftablifhed we may reafon in confequence of them with clearners.

In horfemanfhip, the Body of man is divided into three parts; two of which are moveable, the third immoveable.

The firft of the two moveable parts is the. Trunk or Body, down to the Waift ; the fecond is from the Inees to the Feet; fo that the immoveable part is between the waift and the knees. The parts then which ought to be without motion are the Fork, or Twift of the horfeman, and his thighs; now that thefe parts fhould be kept without motion, they ought to have a certain hold and center to reft upon, which no motion that the horfe can make can difturb or looften; this point or center is the bafis of the hold which the horfeman has upon his horfe, and is what is called the SEAT; now if the feat is nothing elfe but this point or center, it mull follow, that not only the true rrace, but the fymmetry and true proportion of the whole attitude depend upon thofe parts of the body that are immoveable. 
Let the horfeman then place himfelf at once, upon his 1'wift, fitting exact'y in the middle of the faddle; let him fupport this poit ture, in which the Twit alone feems to fuftain the weight of the whole body, by moderately leaning upon his buttock.

Let the Thighs be turned inward, and reft flat upon the fides of the faddle; and in ordier to this let the turn of the thighs proceed directly from the hips, and let him employ no force or ftrength to keep himfelf in the faddle, but truft entirely to thè weight of his body and thighs; this is the exact equilibrio: in this and this only confifts the firmnefs and fupport of the whole building; a firmnefs which young beginners are never fenfible of at firt, but which is to be acquired, and will always be attained by exercife and practife. I demand but a moderate ftrefs upon the buttocks, becaufe a man that fits full upon them can never turn his thighs flat to the faddle; the thighs thould always lay flat to the faddle, becaufe, the flelhy part of them being infenfible, the horfeman would not otherwife be able fo nicely to feel the motions of his horfe: 1 infift that the turn of the Thigh muft be from the Hip, becaufe it can never be natural, but as it proceeds from the hollow of the hip bone.

I infift farther that the horfeman never avails himfelf of the ftrength or help of his thighs, except he lets his whole weight reft upon the cen:er, as before deferibed; becaufe the clofer he preffes them to the faddle, the more will he be lifted above the faddle on any fudden or iregular motion of the Horfe.

Having thus firmly placed the immovable parts, I now pals on to the firft of the Movables, which is 
as I have already obferved the body as far as to the waift. I comprehend in che Body, the Head, the Shoulders, the Breaft, the Arms, Hands, Reins and Waift of the Horfeman.

The head fhould befree, firm and eafy, in order to be ready for all the natural motions that the horfeman may make in turning to one fide or the other. It thould be firm, that is to fay, frait, without leaning to the right or left, neither advanced nor thrown back; it mould be eafy becaufe if otherwife it would occafion a ftifinefs, and that ftiffnefs affecting the different parts of the body, efpecially the back bone, the whole would be without eafe and conftrained.

The fhoulders alone influence by their motions that of the breaft the reins and waift.

The horfeman hould prefent or advance his breaft, by that his whole figure opens and difplays itfelf; he thould have a fmall hollow in his reins, and purh the waif forward to the pommel of the faddle, becaufe this poftion correfponds and unites him to all the motions of the horfe.

Now only throwing the floculders back, produces all thefe effects, and gives them exacty in the degree that is requifite; whereas if we were to look for the particular pofition of each part feperately and by itfelf, without examining the connection that there is between the motions of one part with thole of another, there would be fuch a bending in his reins that the horfeman would be, if I may fo fay', hollow backed; and as from that he would force his breatt forward and his waift towards the pommel of the laddic, he would be flung back, and muft fit upon the rump of the horfe. 
The arms mould be bent at the elbows, and the elbows thould reft equally upon the hips; if the arms were ftrait, the confequence would be, that the hands would be too low, or at too great a diftance from the body; and if the elbows were not kept fteady, they would of confequence, give an uncertainty and ficklenefs to the hand, fufficient to ruin it for ever.

It is true that the Bridle-band is that which abfolutely ought to be fteady and immoveable; and we might conclude from hence, that the left elbow only ought to reft upon the hip; but grace confifts in the exact proportion and fymmetry of a!l the parts of the body, and to have the arm on one fide raifed and advanced, and that of the other kept down and clofe to the body would prefent but an aukward and difagreeable appearance.

It is this which determines the fituation of the hand which holds the whip; the left hand being of an equal heighth with the elbow; fo that the knuckle of the little finger, and the tip of the elbow be both in a line, this hand then being rounded neither too much nor too little, but juft fo that the wrift may direct all its motions, place your right hand, or the whip hand, lower and more forward than the bridle hand. It fhould be lower than the bridle hand becaufe if it was upon a level with it, it would reftrain or obftruct its motions; and were it to be higher, as it cannot take fo great a compars as the bridle hand, which muft always be kept over againft the horfeman's body: it is abfolutely neceffary to keep the proportion of the elbows, that it fhould be lower than the other.

The legs and feet make up the fecond divifion of what I call the moveable parts of the boly: the 


\section{(14)}

legs ferve for two purpofes, they may be ufed as aids or corrections to the horfe, they fhould then be kept near the fides of the horfe, and in a perpendicular line with the horfeman's body; for being near the part of the horfe's body where his feeling is moft delicate, they are ready to do their office in the inftant they are wanted. Moreover, as they are an apendix of the thighs if the thigh is upon its flat in the faddle, they will by a neceffary confequence be turned juft as they ought, and will infallibly give the fame turn to the feet, becaufe the feet depend upon them, as they depend upon the thighs.

The toe fhould be held a little higher then the heel, for if the toe was loweft the heel would be too near the fides of his horfe and would be in danger of touching his horfe with his fpurs at perhaps the very inftant he hould avoid fuch aid or correction.

Many perfons notwithitanding, when they raife their toe, bend and twift their ankle as if they were lame in the part. The reafon of this is very plain; becaufe they make ufe of the mufcles in their legs and thighs, whereas they thould only employ joint of the foot for this purpore,

Such is in fhort the mechanical difpofition of all the parts of the horfeman's body.

Thefe ideas properly digefted the practitioner will be able to prefcribe rules for giving the true and natural Seat, which is not only the principles of juftnefs, but likewife the foundation of all grace in the horfeman, of courfe, the firit endeavour of thofe who wilh to become horfemen, fhould be to attain a firm and graceful feat: the perfection of which, 


\section{$\left[\begin{array}{ll}15 & \end{array}\right]$}

as of mort other arts and accomplifhments depend upon the eafe and fimplicity with which they are executed, being free from affectation and conftraint as to appear quite natural and familiar.

Therefore the immoveable parts as before obferved ought to be fo far without motion as not to wriggle and roll about fo as to difturb the horfe, or render the feat weak and loofe : but the thighs may be relaxed to a certain degree with propriety and advantage, when the horfe hefitates and doubts whether he thall advance or not; and the body may likewife, upon fome occafions, become moveable and change its pofture to a certain degree, as when the horfe retains himfelf, it may be flung back more or lefs as the cafe requires; and confequently inclined forward when the horfe rifes fo high as to be in danger of falling backwards; what keeps a fhip on the fea fteady? BALLAST, by the fame rule, what keeps the horfeman STEAPY? trufting to the weight of his body: it is for this rea ${ }^{2}$ on that beginners are firft made to ride without ftirrups; for were they allowed to ufe them before they had accuired an equilibrio and were able to ftretch their legs an. thighs well down, fo as to fet firmly in the faddle, and clofe to it, they would either loofe their ftirrups by not being able to keep their feet in them; or the ftirrups nult be taken up much too fhort, in which cafe the rider would be puhed upwards from the faddle, and the Seat deftroyed throughout; as the parts of the body like the links of a chain depending upon one another, fafety likewife requires they thould ride without them at firt, as in cafe of falling tis lefs dangerous. 


\section{$(16)$}

It is the general practice of thofe who undertake to teach horfemanhip, when they put a fcholar upon a Horfe, to mix and confound many rules and precepts together, which ought to be diftinct and feperate; fuch as making him attend to the guidance of the horfe, demanding an exactnefs of hand, and other particulars, which they croud upon him before he is able to execute, or even underftand half of them. I would recommend a flower pace at firft being likely to gain morc ground at the ending poft, and not to perplex the fcholar with Aids, of the efrects of the Hain, ard more nice and effential parts of the ART: rill the SEAT is gained and CONFIRMED.

For this purpofe let the feat alone be cultivated for fome time, and when the fcholar is arrived at a certain degrec of firmnefs and confidence fo as to be trufted, I would always advife the mafter to take kold of the longeing rein. and let the pupil intirely leave the governing of his horfe to him, soing fufficiently to both hands holding his hands behind him.

This will, I infift upon it very foon fettle him with firmners to the faddle, will place his head, will ftretch him down in his faddle, will teach him to lean gently to the fide to which he turns fo as to unite himlelf to his horfe and go with him and will give that firmnefs eare, and juft poize of body, which conftitute a perfect Seat, founded in truth and nature and upon principles fo certain, that whoever thall think fit to reduce them to practife will find them confirmed and juftified by it. Nor would it be improper to asciltom the fcholar to mount and difmount on both fides of his horfe, as many things may occur to make it neceflary, as well as that he cannot have too much 


\section{(17)}

much activity and addrefs, for this reafon tis a pity that the art of Vaulting is difcontinued.-And there is another duty too effential to be omitted, but hitherto not performed by mafters, which is to inftruct their pupils in the principles and theory of the Art, explaining how the natural paces are performed, wherein they differ from each other, and in what their perfection confifts; which, by not joining theory with practice, are unknown to many, who may thine in a menage, but work as mechanically and fuperficially as the very horfe thay ride.

Having thus far faid what with practice will be fufficient to form the feat of the Horfeman, I thall next endeavour to defcribe the ufe of the bridle hand and its effects, \&c.

\section{Of The Bride Hand.}

THE knowledge of the different characters, and different natures of horfes, together with the vices and imperfections, as well as the exact and juft proportions of the parts of a horfe's body, is the foundation upon which is built the theory of the art of horfemanthip; but this theory will be ufelefs and even unneceffary if we are not able to carry it into execution.

This depends upon the goodnefs and quicknefs of feeling; and in the delicacy which nature alone can give, and which the does not always beftow. The 


\section{( 18 )}

firft fenfation of the hand confifts in a greater or lefs degree of finenefs in the touch or feeling; a feeling in the hand of the horfeman, which ought to communicate and anfwer to the fame degree of feeling in the horfe's mouth, becaufe there is as much difference in the degrees of feeling in men as there is in the mouths of horfes.

I fuppofe then a man, who is not only capable to judge of a horfe's mouth by theory, but who has likewife by nature that finenefs of touch which helps to form a good hand; let us fee then what are the rules which we fhould follow in order to make it perfeet, and by which we muft direct all its operations.

A horfe can move four different ways; he can ad. vance, go back, turn to the Right and to the Left; but he cannot make thefe different movements except the hand of the Rider permits him, by making four other motions which anfwer to them; fo that there are five different pofitions for the hand. The firft is that general poition from which proceed the other four.

Hold your hand three inches breadth from your body, as high as your elbow, in fuch a manner that the joint of your little-finger be upon a right line with the tip of your elbow; let your wrift be fufficiently rouncled fo that your knuckles may be kept directly above the neck of your horfe; let your finger nails be exactly oppofite your body, the little finger rather nearer to it than the others; your thumb quite flat upon the reins, feparated as before efefribed, and unis the general Pofition. 


\section{(19)}

Does your horfe go forwards, or rather would you have him go forwards? yeild to him your hand, and for that purpofe turn your nails downwards, in fuch a manner as to bring your thumb near your body, and your little-finger then from it, and bring it to the place where your knuckles were in the firit pofition. Keeping your nails directly above the neck of your horfe. - This is the fecond Pofition.

Would you make your horfe go backwards, quit the firf pofition; let your wrift be quite round, your thumb in the place of the little finger in the fecond pofition, and the little-finger in that of the thumb, turning your nails quite upwards, and towards your face, and your knuckles will be towards your horfe's neck. - This is the third Pofition.

Would you turn your horle to the Right? leave the firft pofition; carry your nails to the right, turning your hand upfide down, in fuch a manner that your thumb be carried out to the left, and the little-finger brought in to the Right.-This is the fourth Pofition.

Laftly, would you turn your horfe to the Left? quit again the firft pofition, carry the back of your hand a little to the left, fo that the knuckles come under a little, that your thumb may incline to the right, and the little-finger to the left.-This makes the fifth Pofition.

Thefe different Pofitions, however, alone are not fufficient; we mut be able to pafs from one to the other with readinefs and order.

Three qualities are neceffary to the hand. Viz. FIRM, GENTLE, and LIGHT: I call that a firm hand, 


\section{(20)}

or fteady hand whofe feeling correfponds exactly with the feeling in the horfe's mouth, and which confifts in a certain degree of Ateadinefs, which conftitutes that juft correfpondence between the hand and the horfe's mouth, which every horfeman wilhes to find.

An eafy or gentle hand. I call that which, relaxing a little of its ftrength and firmnefs, eafes and mitigates the degree of feeling between the hand and horfe's mouth, which I have already defcribed.

Laftly, the light hand is that which leffens ftill more the feeling between the rider's hand and the horfe's mouth, which was before moderated by the Gentle Hand.

The hand, therefore, with refpect to thefe properties mult operace in part, within certain degrees, and depends upon being more or lefs felt, or yeilded to the horfe, or with-held.

It hould be a rule with every horfeman not to pafs from one extreme to another; from a firm hand to a flack one; fo that in the motion of the hand on no account jump over that degree of fenfation which conftitutes the EASY OR GENTLE HAND: were you once to go from a firm ftrong hand to a flack one, you then entirely abandon your horfe; you would furprife him, deprive him of the fupport he trufted to, and precipitate him on his houlders; fuppofing you do this at an improper time. On the contrary, were you to pafs from the flack to the tight rein, all at once, you muft jerk your hand, and give a violent thock to the horfe's mouth; which rough and irregular motion would be fufficient to falfify and ruin a good mouth; it is indifpenfably neceffary, therefore, that all its ope- 
perations thould be gentle and light, and in order to this, it is neceffary that the WRIST alone fhould direet and govern all its motions, by turning and fteering it as it were, through every motion it is to make

In confequence then of thefe principles, I infift that the wrift be kept fo round that your knuckles may be always directly above the horfe's neck, and that your thumb be always kept flat upon the reins. In reality were your wrift to be more or lefs rounded than in the degree I have fixed, you could never work with your hand but by means of your arm, and befides it would appear as though you were lame; again were your thumb not to be upon the flat of the reins, preffed hard upon your fore finger, they would be conftantly nipping away, and lengthened, and in order to recover them you would be obliged every minute to raife your hand and arm, which would throw you into diforder and make you lofe that jutnefs without which no horfe will be obedient and work with readinefs and pleafure to himfelf.

It is neverthelefs true, that with horfes well dreffed one may take liberties; thefe are motions called defcents of the hand; either by dropping the knuckles directly and at once upon the horfe's neck, or by taking the reins in the right hand about four inches above the left, letting them nide through the left, dropping your right hand at the fame time upon the horfe's neck, or elfe by putting the horfe under the button as it is called : that is by taking the end of the reins in your right hand, quitting them intirely with your left hand and letting the end of them fall upon your horfe's neck, thefe motions however, which give grace to the horfeman, never hould be 
made but with great caution, and exactly when your horfe is well together and in hand; and take care in counterbalancing by throwing back your body, that the weight of the body lie upon his haunches.

The Bit and Snaffle were they to be kept conftantly in one place in his mouth, would of courfe dull the fenfe of feeling, and become benumbed and callous; this thews the neceffity of continually yeilding and drawing back the hand to keep the horfe's mouth frefh and awake. It is therefore felf evident that a heavy handed horfeman can never break a horfe to any degree of nicety, or ride one which is already broke to any degree of exactnefs.

Befides thefe rules, there are others not lefs juft and certain; (but whofe nicenefs and refinement is not the lot of every perfon to tafte and underftand) my hand being in the firft pofition, I open my two middle fingers, I confequently eafe and flacken myright rein; I fhut my hand, the right rein operates again, refuming its place as before, I open my little finger and carrying the end of it upon the right rein, I thereby flacken the left and fhorten the right; I hut my hand entirely and immediately open it again, Ithereby leffen the degree of tenfion and force of the two reins at the fame time; again I clofe my hand not quite fo much, but ftill I clole it.

It is by thefe methods and by the vibration of the reins, that $I$ unite the feeling in my hand with that in the horfe's mouth, and thus I play with a fine and MADE mouth, and frefhen and relieve the two bars in which the feeling refides. 


\section{$(23)$}

Therefore, it is that correfpondence and fenfation between the horfe's mouth and the hand of the rider, which alone can make him fubmit with pleafure to the conftraint of the bit.

Having thus explained the different pofitions and mutions of the hand, permit me in a few words to thew the effects which they produce in horfeman. hip?

The hand cirects the reins, the reins operate upon the branches of the bit; the branches upon the mouth-piece and the curb, the mouth-piece operates upon the bars, and the curb upon the chin of the horfe.

So far for the management of the bridle hand upon thorough-broke and well-drefied horfes. But in breaking young horfes for any purpofe, the reins in all cafes ought to be feparated, nothing fo unmeaning, nothing fo ineffectual as the method of working with them joined or held in only one hand, this is very evident in the inftances of colts, and of fiff necked, and unworked horfes of all kinds, with them it is impoffible to do any thing without holding a rein in either hand, which rein operates with certainty and governs the fide of the neck to which it belongs, and furcly this is a thorter way of working than to make, or rather attempt to make the left rein determine the horfe to the right, and the right guide him to the left. In the above inftances of ftiff awkward horfes this can never be done; and altho it is conftantly practifed with thofe which are Dreft, yet it is certain they obey, and make their Changes more from docility and $\mathrm{H}_{a}$ bit, than from the infuence 


\section{(24)}

of the outzvard rein, which ought only to act, to ballance and fupport, while the inner bends, inclines, and guides the horfe to the hand to which he is to go.

This can never be done fo fully and truly with the reins joined, as when they are feparated into each hand, and if double or Running reins were ufed inftead of fingle as with a fnaffle or * Meadow's bit, they would afford more compafs and power to the horfeman to bend and turn his horfe.

The manner of holding the reins high as condemed by fome writers, poffeffing themfelves with a notion that they ruin the hocks of the horfes. For my own part I do not know what thofe writers mean, unlefs by them we are to underftand the haunches; and then this method inftead of ruining, will work and affift them, for the head and fore quarters are raifed up, his weight of courfe is thrown upon his baunches, for one end being raifed the other muft be kept down.

It is nothing more than a natural caufe, which will always produce a natural effect, for inftance, ballance a pole upona wall fo that it acts in equilibrium, only raife one end, the other of courfe muft be lowered, it is the fame with a horfe, as you cannot rife his fore parts but by bringing his haunches more under him. I would here wifh to remark that horfes fhould never be compelled by force untill they know what you wifh from them, for let them be however difobedient in their difpofition, yet are all of them more or lefs fenfible of good and bad ufage from their mafters; the beft method then to convey your intention to them fo that they fhall underftand you, is to reward them 
when they do well, and to punith them when difobedient, this rule though contained in few words yet is of univerfal ufe in horfemanfhip.

And Xenophon, who wrote a treatife on Horfemanhip, more thar two thoufand years ago, among other notable remarks, when fpeaking on horfe-breaking, wherein he concludesthus: "But there is one " rule to be inviolably obferved above all others; " that is, never appruach your horle in a paffion; "as anger never thinks of confequences and forces us " to do what we afterwards repent."

Begging pardon for this fhort but ufeful digreffion, I again obferve that fuch are the principles upon which the perfection and juftnefs of the aids of the hand depend; all others are falfe and not to be regarded.- Thus far for the bridle hand, and its effects. 


\title{
LECTURE ON HORSEMANSHIP.
}

\author{
Addreffed to the Ladies.
}

AMONG all the various writers on the art of horfemanhip, notwithltanding, fide-faddles have been known and in ufe in England more then fix hundred years ago, even in Richard's time, for in the reign of this prince fide-faddles were firft known here, as it will appear from the following anecdote, by a Warwick hiftorian, in which he fay's.

"And in his days alfo began the deteftable cuftom "6 of wearing long pointed thoes, faltened with "chains of filver, and fometimes gold, up to the 6r knees, likewife noble ladies then ufed high heads, "6 and robes with long trains, and feats or fide-faddles "6 on their horfes, by the example of the refpectable " queen Anne, daughter of the king of Bohemia, "who firt introduced this cuftom in this kingdom: "6 for before, women of every rank rode as men do, "6 with their legs aftride their horfes."

Thus fays our Warwick hiftorian, fo that fide faddles appear to have been ufed many centuries ago, and that formerly the female fex took the fafhion of riding like men, for which they are reprehended 
hended, by a Greck hiftorian, and hard indeed is the equeftrian fituation of the ladies, for if they are to be accufed of indelicacy for riding after the manner of men, they are greatly to be pitied in hazarding their fafety as they do, in riding after the manner of Women.

However as no one hath ever yet lent a helping hand in putting pen to paper on the fubject, by way of adding, if poffible, to the ladies, elegance, eafe and fafety on horfe back; I thall without any other apology then affuring thofe ladies who may pleafe to read what I write on the matter, is well meant, and are fuch ideas that have occured to me in many years ftudy, and practice in the manage.

\section{DIRECTIONS IN MOUNTING.}

LET the oftler or fervant being on the off fide the horfe, with right hand holding the bridoun reins, to properly ftay the horfe, and his left hand on the part of the faddle called the crutch, by this method both horfe and faddle will be kept firm and fteady, it is the riding mafter's duty to examine the bridle whether it is properly placed, the curb, chain, or chin chain in due order, the faddle in a proper place, and the girths fufficiently tight, E'c. Direct the lady then to take her whip, or fwitch in the right hand, the fmall end of it turned towards the horfe's croup, then with the right hand take a firm hold of the pommell of the faddle ftanding upright with her 


\section{$(28)$}

right moulder fquare, and in a line with the horfe's left, the then bending the left knee pretty much, the mafter or gentleman who afifts her ftanding facing the lady, he itonping a little receives the lady's left foot in his hands being clafped firm together, the lady mut then be directed to ftraiten her knee, being now bert, with a firmnefs and elafticity preffing her left hand on the man's left lhoulder, making a little fpring at the fame time, by which the ridingmafter, gentleman, or fervant, if permitted, by paying due attention to thefe rules will fpring the lady on the faddle with the greateft eafe and fafety. The metbod of adjufting the petticoats; I then place the lady's foot in the ftirrup tho' it is a wonder if a proper length, being guefs work, as we are now to fuppofe this to be the firft leflon, and the ftirrup cannot be properly fixed, till the lady is in her feat, I fay I then give her the ftirup, directing the may take a firm hold with the left hand of a lock of the horfe's mane, at the fame time the having a firm hold of the crutch with the right, by which means the rifes herfelf up from the faddle, ftanding firm in the ftirrup, looking rather over the off fide of the horfe's neck, the intention of this is that the attendant thall adjuft the coats fo as they fit fmooth and eafy, by pulling them round a little to the right, then on returning to the faddle, or feat, and while in coming down the muft put her right knee over the pommel of the faddle, and by thefe fimple rules the will find all comfortable and eafy; in regard to the adjuftment of the bridle reins, and the managing and directing the horfe by them, pay ftrict attention to thofe fet down in the firft lecture addreffed to the gentlemen; let the whip be placed firm and eafy in the right hand, with the taper or fmall end downwards, 


\section{(29)}

wards, and the arm hanging carelefsly down without contraction, and when the whip is made ufe off, let it be by means of the writt, without lifting the arm from the body, and be careful not 10 touch the horfe with the whip too backward as many of them will kick on their being flogged in that part, which if it thould not occafion a fall, would much alarm the young fcholar, before the has acquired any degree of ballance.

DIRECTIONS FOR THE LENGTH OF THE STIRRUP.

THE Stirrup fhould be fuch length as when the lady fits upright and properly on her feat, with the knee being eafily bent, the heel kept back, with the toe raifed a little higher than the heel, fo that the heel, hip and the houlder, are in a line and as upright as when walking along, for if otherwife it is unjuft and not agreeable to nature; for fuppofe you are riding along the road with the foot ftuck out and fo forward as the horfes front of his fhoulder, as is not uncommon to fee girls riding in this manner along the rad in the country, as tho' they were directing with their foot which road their horfe fhould take, I fay this method is not only very unhecoming but very unfafe, for inftance if riding carelefsly along the road with the foot and leg in this attitude being to pafs forne ftubborn or inflexibie object on the left or near fide, perhaps before you are aware or 


\section{$(30)$}

apprifed of the danger you might have your foot and leg forely bruifed, nay even dragged from your horfe, I have feen fimilar inftances to this, happen more than once, even when the foot has been in a good fituation by ladies who unthinkingly have endeavoured to pafs objects to the left when they could as eafily have paffed thofe objects to the rigbt, which ladies thould make an invariable rule fo to do at all times, if poffible; for reafons which muft be plain to any one, who will think one minute on the matter; another inconvenience will frequently arife by fuffering the leg and foot to be in this horrid form, which is, the ftirrup leather will frequently prefs againft the leg, fo as to hurt it very much, this I have often had beginners complain of, by faying the buckle of the ftirrup hurt them, when behold I never ufe a buckle to my ftirrups on the left fide, as they are always faftened and buckled on the off fide, for two particular good advantages which arife from it; the principal of which is, that as the preffure or bearing coming from the off fide, it greatly affifts in keeping the faddle even, efpecially with thofe ladies through a bad habit who accuitom themfelves to bear hard on the firrup which is nothing more then a habit, and want of learning to ride the right way at firf.

The other reafon is, you can lengthen or fhorten the ftirrup at pleafure, without difturbing the lady at all, and without even difmounting yourfelf, if you are riding on the road, as the bufinefs is done on the off fide the horfe, nay I have altered the ftirrup often without ftopping at all.

I infift upon it therefore if the ftirrup does not hang perpendicular, or the fame as when left to itfelf and 


\section{( 3 I )}

no one on horfeback, the end is totally deftroyed, for what the ftirrup was defigned; which is in the firft place to carry the weight of, and only the weight of the rider's leg, without which fupport it would foon become fatigued and tired : and fecondly, if you accuftom yourfelf to carry your foot properly, as before directed, that is your heel in a line with your hip and fhoulder, letting your foot reft even in the ftirrup, carrying only the weight of your leg, with the toe a little raifed, it will never fail to affift you in your balance, if you happen to lofe it to the left, it is aifo ready to fave you if you thould happen to lofe your balance to the right, by preffing the calf of your leg ftrongly and firmly to the fide of your horfe, an $\rfloor$ being always near your horfe's fide it is a quick aid in fupporting him, and to force him forward, it is alfo of the greateft ufe, by preffing it ftrongly to his fide, in affifting to turn your horfe to the left, and likewife in throwing your horfe's croup off when you wilh to make him go into a canter, by which means he will be forced to go off with the right leg foremoft.

And laftly, it is of the utmoft utility in fupporting you in the continuance of the Spring Trot, a pace now greatly in fafhion, and thould be practired by all who accuftom themfelves to ride any. length of journies, as it enables them to make fome degree of fpeed, and by changing their paces often from walk, to trot, and gallop, their journey becomes lefs tedious to them. 


\section{Of The Seat,}

\section{And Form of the Side Saddle.}

In the firft place I would ftrongly recommend a large feated Saddle, very high on the cantlet or back part, and a regular fweep from thence to the front or pommell, for fome faddles, more thame be it fpoken, are fo fmall, and the feat fo rounded in the middle, that to fit on them is next to balancing themfelves on a round pole, a comfortable fituation truly for a lady! I fay ayain let me recommend a large feated faddle; I mean let it be large in proportion to the fize of the lady, and high in the cantlet, nay I am confident that they might be contrived to advantage, were they conftructed with peaks, and the peak carried on from the back part of the faddle to within four inches of the front on the off fide; this with the addition of a Burr, as it is called, to fupport the left knee, would greatly affift the lady in keeping the body on a good balance and fufficiently back: which might prevent many accidents.

If thefe hints fhould ftrike any lady or gentleman as being reafonable, and fhould they be inclined to have a faddle fo conftructed, I fhould think myfelf happy in explaining myfelf more fully on the fubject.

Now in regard to the Seat for a Lady, I fincerely wifh I was able to prefcribe a more firm one than the prefent fafhion will admit of, however I will do 


\section{(33)}

my endeavour to handle it in the beft manner I can ; and firft let the whole weight of the body reft firmly upon the center of the faddle, leaning nei her to one fide or the other, with rhe fhoulders eafily back and the cheft prefented well forward; a lady not be too nice and circumfpect, in accuatoming herfelf to fit upright, without contraction, in any part, notbing fo graceful, notbing fo fafe as eare of a: i ion; do not let the ftirrup carry more than the weight of the leg, except in cafe of the Swing Trot, or when affifting to keep the Ballance,

Two material difadvantages arife from Ladies accuftoming themfelves to bear heavy in the firrup, and loll about, conftantly twifting themfelves to the near or left fide of the horfe: firf it deftroys their whole figure, making the fame appear deformed and crooked; and if they were to continue in the habit of riding would confirm them in fuch deformed attitude, in its becoming fecond nature, by conflant ufe; this is a truth too frequently witneffed, by practifing without the right method.

Secondly, the other difadvantage moft materially affects the horfe; for by their fo conftantly leaning themfelves to the near fide, the fide-faddle being fo pulled and preffed againft the withers or fhoulder of the horfe on the off fide, heeping up a continual friction, and this being the care, I defy all the Sadlers in the kingdom to prevent the faddle fron: wringing and galling the poor beaft, efpecially in the heat of the fummer; the only remedy is to take away the caufe, by fitting properly, and the effect cenfes of courfe. 


\section{(34)}

The notions which fome Ladies have entertained, as to fear to let their daughters be taught to Ride, leaft it hould make them grow crooked and awry, I infift that they are falfe, and quite the reverfe; the caufe is, as before obferved, by their contracting bad habits of their own, and not being infructed on approved principles. fo that the effect is caught hold of, while the caufe lies unfought for ; from my own lnowledge and experience I could relate feveral in. ftances wherein young Ladies inftead of growing crooked by learning to ride, have been greatly relieved from thofe complaints, and even quite eradicated by the practice of riding, I will here beg leave to mention an infance or two which will ferve to prove what good effects may arife from this pleafant and healthful exercife.

A young Lady about Seventeen years of age who had been afflicted for twelve months with a Atiffnets in her neck and thoulders, and it was obfervable that the right houlder was grown much larger than the left.

She on coming to the riding houfe to obferve her fellow fcholars take their leflons, of which the became much pleafed, and withed much to learn to ride.-The governefs confulted me on the natter, but faid the feared it might make her grow worfe as the had been told that riding fometimes caufed Ladies to berome crooked, however, by my reafoning the matter with her the was convinced in her own opinion and caufed the young Lady to write to her parents in Jamaica, and had permiffion by return of packet to ride according to my directions, which were briefly as follows, being in the month of March, and of courfe rather a cold picrcing air, I advifed 


\section{(35)}

new unwafhed flannel every time the touk a leffon to be worn next the fkin on the part affected, Jhe rode, of courfe a ftrong perfpiration took place, the was much fatigued for the firlt fix or feven Leflons, however after then as the began to be acquainted with the ufe of her bridle hands, as I made her ufe both; and give great part of the Leffons, in fmall circles to right and left; the confequence was that by perfevering in this method for two fucceffive months the parts became naturally relaxed and pliable, and by continuing to practice the entirely recovered her alacrity and fpirits, and alfo became acquainted with the art of Riding, which I hope the may long live to practice with eafe and fafety to herfelf in her native country.

Another young Lady from the fame fchool had a particular habit of leaning her fhoulders and neck forward, I have frequently heard it called pokeing, and all the dancing-mafter's inftuctions had for years been ineffectual. I believe the was more fond of riding than dancing infructions, for the governefs of the young lady before-mentioned often afferted that the Riding Mafter had done more in fetting her fcholar upright and keeping her fhoulders eafily buck, in the fpace only of two months, than the Dancing Mafter, though capable in his profeffion, had been able to accomplifh in three years.

I hope to be pardoned for this little digrefion, not doubting but thofe Ladies who will give themfelves time to confider the foregoing, will be convinced that it is agreeable to reafon and nature.

Now to fay fome little more of the SEAT, which cannot be too much attended to, being in a great 


\section{$\left(3^{6}\right)$}

mcafure the foundation of fafety to a lady when on horfeback, and as fuch I would frongly recommend the lady being in the menage, or in any proper place, the hoife being very quiet and to be trufted to; then let the lady feat herfelf properly on the faddle as before directed, only without the ftirup, and not to take the reins, Jeaving the direction of the horfe to the Riding Mafter, or to whocver the can with fafety truft the government to; and in this manner take half an hour's practice every day, as nothing will fo greaily affin in acquiring a good and juft balance.

I do not advife this method to be gone rapidly about, as the may make ufe both of ftirup and reins at firit, and when the has acquired a firmnels and balIance in fome degree, may firft quit the ftirrup, and in a lefion or two, the reins. remembering to go to right and left circle alternately and progreffively. viz. from Walk to Trot and Gallop; I hope I need not fay that the horfe thould be remarkably tteady, and properly broke to go in circles to right and left by the longeing rein.

I fay this method will fettle and give the fcholar a firmels not to be acruired by any other means, will teach them to unite themfelves with their horfe, and go along with him, it will bring about that con fidence, firmmefs, eafe, and jutt poize of body which ferves to conititute what is called a perfect Seat, acquired by the rules of art, and agreeable to nature, and I here beg leave to quote a few lines which the great Perringer obferves applicable to this fubject, "It is aftonithing to think how this work fo "immediately necefiary could have been deferred "fo long, that while rewards were given, public triic als appointed, and laws enacted to promote an ufe- 


\section{(37)}

"ful and generous breed of horfes, noftep Thould have

" been taken on the other hand to q alify and inftruct

" the youth of the kingtom, of boin $f \mathrm{ex}$ in the

"fuperior art of riding; for the getting on the back

" of an horfe to be conveyed from one place to an-

" other without knowing what the animal is enabled

" by nature, art and practice to perform, is not

" Riding, the knowledge and urility of which

" confitts in being able to difcern and dexierous

" to empluy the means by which the horfe may be

" brought to execute what the rider requires of him

"with propriety, readinefs and fafety, and this

" knowledge in the rider and obedience in the horfe

" hould be fo intimately connected as to form one

"perfer whole, this union being fo indifpenfably

" neceflary that where it is not, there is no meaning,

" the rider and horte talk different languages, and

"all is confufion, while many and fatal milchiefs

s6 may enfue, the rider may be wedged in the tim-

" ber which he ftrives to rend, and fall the victim

of of his own ignorance and rafhnefs."

I have now obferved fuch rules which with practice will form as good and perfect a Seat as the cuftomary mode of riding will admit of. It remains now with practice and perfeverance to make perfect.

WHEN RIDING ON THE ROAD.

IVHEN a lady has taken fufficient practice in the menage or elfewhere, fo as to be able to fteer and guide her horfe, and particularly canftop him firm and well upon his haunches, and alfo knows by practice lrow to unite herfelf to the horfe, provided he fhould

ftop 


\section{$\left(3^{8}\right)$}

ftop fuddenly by his own will, an inftance which frequently happens, therefore it is efiential that the rider fhould become fenfible of every action of the horfe by that kind of fympathy of feeling which fhould fubfift between them, fo as to know his intentions as quick as thought, in this and all cther acions he may be inclined to, which are likely to offend and endanger the rider, or himfelf; I would earneitiy recommend the laciy to make herfelf acouai:ted with every help fo as to gaurd and defend heifelf on all occafions, fuch as her horfe ftumbling, firying, ftarting, running away, running back, rearnng, kicking, and plunging; yet horfes addicted to any of thofe vices are by no means fit, or thould have ladies fet upon knowingly, but as a lady cannot always be fo fortunate as to get the poffeffion of one of thofe hackneys we call a nonpareil, tho' every dealer you enquire of for one will fay he can fell it you, therefore place not too much confidence in him you purchafe your horfe from, or the liorfe himfelf, even after you have rode him fome time, for you fcarce ever can be certain but he may play you fome of thofe tricks, efpecially if his keep is above his work, as I have alway's found the beft lady's hackrieys require conftant practice to keep them in tune.

It is neceffary the lady fhould have a harp eye upon the road the is travelling, taking care by the gentle affiftance of the bridle hand to fteer and guide her horfe into the beft, to avoid all ftones and uneven places, and never to ride near the edge of any teep ditch or fudden precipice, for altho, heaven be praifed, accidents very feldom happen, yet if for the want of a little care and due management one flould happen in one hundred years, that one would be one too many: the lady hould pay great attention 


\section{(39)}

tion to the horfe when going down a fteep hill, and endeavou: to pur hin together and upon his haunches, and $t)$ perfor $n$ this, the muit feel his mouth lightly and firmly with the bridle hand, at the fame time muking ufe of lome of the helps ufed to force him to go to ward, fuch as clicking with your voice, a gentle touch with the whip, or the heel, fo the ftays him a little by the bridle hand at the fame time he is forced forwards by the ether helps or aids and if properly timed, by doingenough without over doing, he will be put together, and of courfe kept on a light proper action which muft be in the real action of a trot, that is with his two corner legs in the air at one time and two on the ground, by fuch means the horfe will always be kept on a fure ballance and never be in danger of falling, on the other hand if the horfe is fufferd to go loole and unafifted by the bridle hand, and the other aids as before defribed, when going lown a fteep hill he will moft commonly go into that unnatural pace called the amble which is moving his fide legs together inftead of his corner legs, this pace is very unfafe notwithftanding the ancients ufed arts in breaking the horfe to the amble, on account of its being fo much eafier than the trot, but as it is a known maxim in phyfic that giving eafe and performing a cure are two different things, fo here an eafy pace and a fafe one are as diametrically oppofite, and that the amble is an unfafe pace is enfy to be conceived by the horfe lofing fo large a portion of his ballance, to prove which only try thefe fimple experiments. Take a wooden horfe let his two corner legs be taken away and he will ftand, but take away his two fides leg and he falls, again. one often fees at a farrier's thop when a horfe is wane. ed to be fhod in hafte, two fmiths can work at the fame time, by taking each of them a corner leg, therefore 


\section{$\cdot(40)$}

therefore how careful hould we be to keep our hackneys on a fafe action, and awake under us on all occafions.

The lady fhould endeavour to make herfelf acquainted with thofe objects, which horfes are moft fubject to be alarmed at, and firt of all is a windmill in full fail, next fome can never be brought to go comfortably by a tiked waggon, efpecially if meeting it, others dinike affes very much, fome difike to face a man wheeling a barrow or an umbrella extended, an arch drain which is frequently feen to carry the water away thro the banks in a turnpike road, its laying low and of courfe prefents itfelf very fuddenly, will fadly alarm fome, and any object fuddeniy prefenting itfelf is almoft fure to affright and alarm any horfe in fpirits, I once fav a lady get a fall, by a cow fuddenly prefenting its head over a hedge, yet a more fteady animal never was, as I ufed her four years and never knew her fart either before or after; let it be remembered that horfes are inore apt to be thy or ftart in the durk of the evening than in broad day light, horfes with bad eyes are almoft fure to ftart, yet ftarting is not a fure fign of bad eyes, as many imagine it, I mention thefe few obfervations in regard to ftarting becaufe horfes which are moft free from thofe faults, it may happen to fome times; as horfes like menare not alway in the fame temper: never ride on a faft pace by any lane's end, or in turning any fidden or fhort turn, for two reafons; firft, that it is unfafe as the horfe might be fubject to fall for want of being fupported, and put together - by thortening his pace, and fecondly by your not being able to difcern the objects which might prefent themfelves to you fo as to difturb and alarm your horfe: thefe little hints kept well in mind may be the means of preventing many accidents. 



